Article

\title{
Willingness to Pay for Recreational Benefit Evaluation in a Wastewater Reuse Project. Analysis of a Case Study
}

\author{
Verlicchi Paola ${ }^{1,2, *(\mathbb{D})}$, Al Aukidy Mustafa ${ }^{1}$ and Zanni Giacomo ${ }^{1}$ (1) \\ 1 Department of Engineering, University of Ferrara, Via Saragat 1, 44122 Ferrara, Italy; \\ mustafakether.alaukidi@unife.it (A.A.M.); giacomo.zanni@unife.it (Z.G.) \\ 2 Laboratorio Terra \& Acqua Tech, Technopolo Ferrara, University of Ferrara, Via Borsari 46, 44121 Ferrara, Italy \\ * Correspondence: paola.verlicchi@unife.it; Tel.: +39-0532-974-938
}

Received: 21 June 2018; Accepted: 10 July 2018; Published: 11 July 2018

\begin{abstract}
The study deals with the evaluation of the recreational benefit of a reclaimed water reuse project in the municipality of Ferrara, north Italy, by means of the contingent valuation method. It also provides an analysis of the public acceptance of the project, determined by eliciting the willingness of the local people to contribute to the realization of this project in monetary terms (their willingness to pay). The project involves the upgrade of the existing wastewater treatment plant by conventional (rapid sand filters) and natural (constructed wetland) treatments. The latter will be constructed within the urban park surrounding the wastewater treatment plant area and will combine the objectives of both wastewater treatment with recreational services, since they will create equipped green areas open to the public. The study is based on the answers provided by 400 respondents, who are residents in the four districts of the municipality of Ferrara. It emerges that willingness to pay is strongly influenced by the socio-economic characteristics of the respondents, with an amount on average of $48 € /$ family.
\end{abstract}

Keywords: contingent valuation method; reclaimed water reuse; recreational benefits; willingness to pay

\section{Introduction}

Technical and economic feasibility evaluation of reclaimed water reuse projects for different purposes is becoming a need. The main reasons are increasingly frequent dry summers in the Mediterranean countries together with an awareness of the increasing deterioration of surface water quality due to the release of treated and untreated effluents and the withdrawal of larger volumes of fresh water for rural, civil, and industrial demands [1,2]. The main difficulties in completing direct reuse projects of treated wastewater are related to the investment and operational/maintenance costs of adequate end-of-pipe treatments and the stringent quality standards requested for the reclaimed water to be reused. For instance, in Italy there are 55 parameters to be fulfilled for the reclaimed effluent to be reused [3]. Even in regions characterized by an abundance of "fresh" water, such as the Italian Po Valley, economic and technical feasibility studies concerning the upgrade of existing wastewater treatment plants have been carried out in recent years in order to produce an effluent adequate for agricultural needs. Verlicchi et al. [4] reported the main findings of a reuse project called FIDEP aimed at completing the treatment of the secondary effluent of the municipality of Ferrara, northern Italy, by conventional (rapid sand filters within the existing wastewater treatment plant (WWTP) boundaries) and natural systems (constructed wetlands developed in the adjacent urban park). These treatments, tested at pilot scale [4,5], were then designed in order to also enlarge the urban park, creating recreational areas and small ponds for free access to park users and to the population in general. 
In evaluating the feasibility of a reuse project of reclaimed water, attention is generally devoted to the technical aspects concerning the treatment train able to guarantee respect of the local legal requirements for the final effluent in relation to its purpose (civil, rural, and industrial direct reuse) [6]. However, efforts to reduce and optimize the investment and operation and maintenance costs must also be made. In some cases, a cost-benefit analysis of the project is also carried out [4,7-9] that aims to evaluate the different benefits related to the project itself. In this context, it is worth noting that recreational benefits could become decisive in the economic feasibility of a project [4].

Moreover, the participation of the local population in the decision-making process and in questions concerning public issues increases awareness of the problems under discussion and could also be of benefit in terms of acceptance of the project itself. As remarked by Tziakis et al. [10], the construction/upgrade of a wastewater treatment plant must be "approved of" by the residents, who should also be willing to pay for its construction and operation.

In this context, in order to evaluate the economic feasibility of the projects, the contingent valuation method (CVM) can be effectively used to enhance the non-market benefits associated with this type of project, for example for recreational and landscape benefits, in order to estimate the total economic value of the investments. It allows the value of non-market goods and services to be determined and is the most widely-used method in evaluating environmental assets by surveying people's willingness to pay for such an asset and/or what they would be willing to receive by way of compensation in order to tolerate such a cost; i.e., preservation of a natural park, or the upgrade of a wastewater treatment plant [11].

Numerous studies have been published dealing with the application of CVM in different parts of the world in the case of reclaimed water reuse projects [10,12-16], sustainable drainage systems and flood risk reduction [17,18], improvement in the surface water quality for nutrient reduction [19], improvement of the water quality used for irrigation needs [20], for coastal water depollution [21], and finally, for tap water quality improvement [22]. Details of these studies are reported in Table 1, together with their aims and main results. It is worth noting that in most analyses referring to reclaimed water reuse, the willingness to pay (WTP) is related to the availability of water for irrigation needs in areas with water scarcity [12] or drought periods [14]. In one case, it is related to a reuse project designed to tackle the consequences of climate change on water availability [23].

This paper focuses on the contingent valuation approach included in the cost-benefit analysis of the reuse project presented and discussed in Verlicchi et al. [4] for the evaluation of the concomitant recreational benefit. It aims to underline the rationale behind the development of the questionnaire used to evaluate the willingness to pay of the potential users of the urban park, which is the area under study. The previous study carried out an evaluation of the investment, operational, and maintenance costs, discussed the different benefits derived from the realization of the project and evaluated them. Referring to recreational benefit, the study rapidly presented the methodology applied and provided the results based on a sample of 146 respondents, which was considered sufficiently representative of the whole potential user group of the urban park. The aim of this study was to provide readers with methodological considerations and choices which could be useful in other similar studies in this field. In this study, we present a new, more comprehensive version of the survey, in which we have expanded the sample to 400 respondents, and have analyzed the distribution of their responses in greater depth. 
Table 1. Selection of published studies applying contingent valuation method (CVM) in cost-benefit analyses of different projects, grouped according to the study scope and country.

\begin{tabular}{|c|c|c|c|}
\hline Country & Aims & Main Results & Ref. \\
\hline \multicolumn{4}{|c|}{ Reuse of reclaimed water } \\
\hline Spain & $\begin{array}{l}\text { To estimate the non-market benefits that society attaches to the reuse of } \\
\text { reclaimed wastewater for agricultural purposes, using the CVM. }\end{array}$ & $\begin{array}{l}\text { The study refers to the Segura river basin in south eastern Spain, which is a region characterized by } \\
\text { severe water scarcity and whose most important sector is agriculture. It has been proven that the local } \\
\text { population obtains significant social non-market benefits from this form of water reuse, expressed via } \\
\text { the willingness to increase the amount of money paid for this purpose. An average willingness to pay } \\
\text { (WTP) value of } € 5.13 \text { month }^{-1} \text { household }{ }^{-1} \text { was obtained. }\end{array}$ & [12] \\
\hline \multirow{4}{*}{ Greece } & $\begin{array}{l}\text { To determine whether the citizens of Thessaly are eager to accept water reuse } \\
\text { incorporated in water management plans in their area: farmers in buying } \\
\text { reclaimed water and consumers in buying products irrigated with that water }\end{array}$ & $\begin{array}{l}\text { Recycled water may be used as an alternative water resource in cultivation areas near the treatment } \\
\text { plants in the Thessaly region. Farmers are willing to pay for recycled water when fresh irrigating } \\
\text { water is not available. Consumers are willing to consume products irrigated with recycled wastewater. } \\
\text { Farmers and consumers who have no information regarding water recycling are unwilling to pay } \\
\text { because they are worried about health and safety issues. }\end{array}$ & [13] \\
\hline & $\begin{array}{l}\text { To investigate farmers' WTP for using recycled water for irrigation purposes } \\
\text { in the Thessaly region, Greece. }\end{array}$ & $\begin{array}{l}\text { Farmers are willing to pay for recycled water, especially during drought periods. The majority of } \\
\text { farmers ( } 57.9 \%) \text { are willing to pay half of the price of fresh water in order to buy recycled water for } \\
\text { crop irrigation. A relatively high percentage of them }(33.6 \%) \text { would not pay for recycled water if they } \\
\text { had fresh water available for crop irrigation, while a very low percentage of farmers (8.4\%) would pay } \\
\text { a little less than price of fresh water for recycled water. }\end{array}$ & [14] \\
\hline & $\begin{array}{l}\text { To identify the perception, experience and the WTP of farmers in using } \\
\text { reclaimed water for irrigation in a semi-arid region of Crete, Greece. }\end{array}$ & $\begin{array}{l}\text { Farmers' perceptions and acceptance of reclaimed water are influenced by several factors including } \\
\text { their level of trust in the local authority, prejudice, and the need for water source. } \\
\text { Half of the respondents ( } 46 \% \text { ) are willing to pay for reclaimed water. Moreover, } 45 \% \text { of respondents } \\
\text { stated that they are willing to invest in agriculture (pay for new irrigation systems, automation, } \\
\text { planting of new crops, etc.). }\end{array}$ & [15] \\
\hline & $\begin{array}{l}\text { To investigate the WTP of the residents of the municipality of Kissamos, } \\
\text { northwest Crete, Greece, for the provision of a central WWTP and of farmers } \\
\text { for recycled water }\end{array}$ & $\begin{array}{l}\text { All residents agree with the construction of a WWTP. Residents are willing to pay for the WWTP on } \\
\text { average } 93.0 \% \text { ( }=€ 21 \text { ) of the amount they pay for their drinking water bill. Farmers are also willing to } \\
\text { pay on average } 61.2 \% \text { (=€ 0.0872) of the price of fresh water for recycled water. }\end{array}$ & [10] \\
\hline Australia & $\begin{array}{l}\text { To investigate community attitudes to recycled water with regard to price and } \\
\text { quality (mainly color, odor, and salt) when used for various purposes. } \\
\text { To estimate the WTP for quality improvements to the recycled water. }\end{array}$ & $\begin{array}{l}\text { Recycled water should be low in salt, colorless, odorless and low in price in order to be accepted by } \\
\text { the community. Interviewed people are most willing to pay for an increase in the quality of recycled } \\
\text { water for clothes washing. The WTP was found to vary according to demographic sector, with those in } \\
\text { the higher income sector found to have a higher marginal valuation of cost, along with those in higher } \\
\text { education, middle age, and male categories. }\end{array}$ & [24] \\
\hline Brazil & $\begin{array}{l}\text { To assess the economic viability of greywater treatment and reuse, and to } \\
\text { identify the WTP of the population for such a system. }\end{array}$ & $\begin{array}{l}\text { Greywater treatment systems are economically feasible. } 63 \% \text { of respondents are willing to pay up to } \\
\text { about US } \$ 630 \text { for the greywater reuse system, but the predominant price range that the respondents } \\
\text { are willing to pay is US } \$ 160-475 \text {, indicating that generally, people are more interested in low cost } \\
\text { systems. }\end{array}$ & [15] \\
\hline Canada & $\begin{array}{l}\text { To examine the degree of public acceptance in Canada for supplementing } \\
\text { existing water supplies with reclaimed water. } \\
\text { To assess the public's WTP for the use of reclaimed water for toilet flushing in } \\
\text { order to avoid water use restrictions. }\end{array}$ & $\begin{array}{l}\text { The majority of Canadians believe that climate change will have a negative impact upon the } \\
\text { availability of future water supplies. They would accept reusing reclaimed water for specific needs } \\
\text { and would contribute to this project. The average annual household WTP was found to be around } \\
\$ 150 \text {, which represents a } 30 \% \text { increase in the average family annual water bill ( } \$ 450) \text {. }\end{array}$ & [23] \\
\hline
\end{tabular}


Table 1. Cont.

\begin{tabular}{|c|c|c|c|}
\hline Country & Aims & Main Results & Ref. \\
\hline \multicolumn{4}{|c|}{ Water quality improvement } \\
\hline India & $\begin{array}{l}\text { To investigate the interests and perceptions of government stakeholders and } \\
\text { famers regarding the treatment of river water for irrigation.To explore the } \\
\text { farmer and consumer's WTP for vegetables that are irrigated with treated } \\
\text { river water. } \\
\text { To survey the views on policy instruments that could help with the } \\
\text { implementation of a treatment system. }\end{array}$ & $\begin{array}{l}\text { Government institutions are aware of the health problems for the farmers and consumers of } \\
\text { vegetables, caused by using untreated river water for irrigation. } \\
\text { The government should support farmers in creating constructed wetlands, but farmers and consumers } \\
\text { should be paid for their operation and maintenance. }\end{array}$ & [20] \\
\hline Kazakhstan & $\begin{array}{l}\text { To investigate the rural peoples WTP for the piped water supply using CVM } \\
\text { for the Pavlodar Region, Kazakhstan. }\end{array}$ & $\begin{array}{l}95 \% \text { of respondents were willing to be connected to the piped water system. Out of these, more than } \\
\text { half were ready to pay the fee of } 20,000 \mathrm{KZT} \text { for the individual connection. The mean WTP for the } \\
\text { maintenance of the individual piped water system was about } 1120 \text { KZT per month per household in } \\
\text { the bid format and about } 1590 \text { KZT per month per household in the open-ended question format. For } \\
\text { the public standpipe, the mean WTP was about } 950 \text { KZT per month per household in the open-ended } \\
\text { category answers, and about } 610 \text { KZT per month per household in the bid format. }\end{array}$ & [25] \\
\hline Korea & $\begin{array}{l}\text { To estimate the WTP for tap water quality improvement in Pusan, Korea, } \\
\text { through the application of CVM. }\end{array}$ & $\begin{array}{l}\text { The monthly mean WTP estimate was } \$ 2.2) \text { per household. This value amounts to } 36 \% \text { of the monthly } \\
\text { water bill and } 20.2 \% \text { of the water production costs. }\end{array}$ & [22] \\
\hline Thailand & $\begin{array}{l}\text { To measure the environmental benefits derived from coastal water } \\
\text { depollution, associated with the proposal of the construction of a new WWTP }\end{array}$ & $\begin{array}{l}\text { The mean WTP for the proposed WWTP project is } \$ 73.36 \text { per household per year, translating into an } \\
\text { aggregate monetary benefit of } \$ 298,774 \text { per year for the local community. On the basis of the } \\
\text { Cost-Benefit Analysis, the proposed WWTP is economically feasible. }\end{array}$ & [21] \\
\hline USA & $\begin{array}{l}\text { To estimate the benefits resulting from nutrient reductions that will maintain } \\
\text { or improve surface water quality in Utah. }\end{array}$ & $\begin{array}{l}\text { Utah households which make use of Utah's waters ("Users") are willing to pay up to } \$ 13.63 \text { monthly to } \\
\text { prevent the deterioration of water quality, whereas nonusers are willing to pay up to } \$ 8.31 \text { per month. } \\
\text { Furthermore, users are willing to pay up to } \$ 32 \text { per month to improve water quality in areas that have } \\
\text { already been or are expected to be degraded by excess nutrients. }\end{array}$ & [19] \\
\hline \multicolumn{4}{|c|}{ Flood risk reduction } \\
\hline Hong Kong & $\begin{array}{l}\text { This study used contingent valuation to investigate the perception of city } \\
\text { residents towards a sustainable drainage system (SuDS) and their WTP for its } \\
\text { implementation. }\end{array}$ & $\begin{array}{l}\text { The Hong Kong residents support the implementation of SuDS and would encourage government } \\
\text { agencies and private property developers to adopt SuDS. }\end{array}$ & [17] \\
\hline Poland & $\begin{array}{l}\text { This study presents the application of the contingent valuation method to } \\
\text { estimate expenditures on flood risk reduction and WTP for wastewater } \\
\text { treatment. }\end{array}$ & $\begin{array}{l}\text { The vast majority of respondents consider the protection of polder areas to be reasonable. The study } \\
\text { showed that } 83 \% \text { of residents agreed to the construction of wastewater treatment plants and were } \\
\text { willing to pay for their construction and operation. }\end{array}$ & [18] \\
\hline
\end{tabular}




\section{Methodology}

\subsection{Study Site}

A complete description of the study area is reported in Verlicchi et al. [4]. Briefly, it is in the municipality of Ferrara $\left(44^{\circ} 50^{\prime} 16^{\prime \prime} \mathrm{N}, 11^{\circ} 37^{\prime} 14^{\prime \prime} \mathrm{E}\right)$, (Emilia Romagna; North Italy), in the eastern part of the Po valley, $50 \mathrm{~km}$ far from the Adriatic Sea. This is a rural area whose main activity is agriculture. It was declared an area at risk of environmental crisis in 1989 by the Italian Ministry of the Environment because prolonged periods of drought can reduce the availability of natural water and surface water bodies are subjected to recurrent eutrophication phenomena. The more stringent quality standards for the discharge of WWTP effluents into surface water bodies set by the law (D. Lgs 152/2006) [26] for these "sensitive areas" are not enough to avoid the risk of environmental crises, which could dramatically reduce fresh water availability and worsen its quality, thus having serious potential consequences during the irrigation period (from May to October).

The possibility of directly reusing reclaimed water from the local WWTP has already been investigated [4]. This investigation highlighted the possibility of upgrading the existing treatment plant (pretreatment, activated sludge system for the removal of carbon, nitrogen and phosphorous compounds, and disinfection) by means of conventional (rapid sand filters) and natural technologies (constructed wetlands).

These end-of-pipe treatments should be placed in the area adjacent to the existing WWTP, which is the urban park of the town of Ferrara (Figure 1A). For this reason, the developed project, called FIDEP, proposed the construction of "treatment isles" by adopting subsurface flow systems and lagoons (Figure 1B-D) and a part of these systems was to be considered the base of cycle paths (Figure 1C).

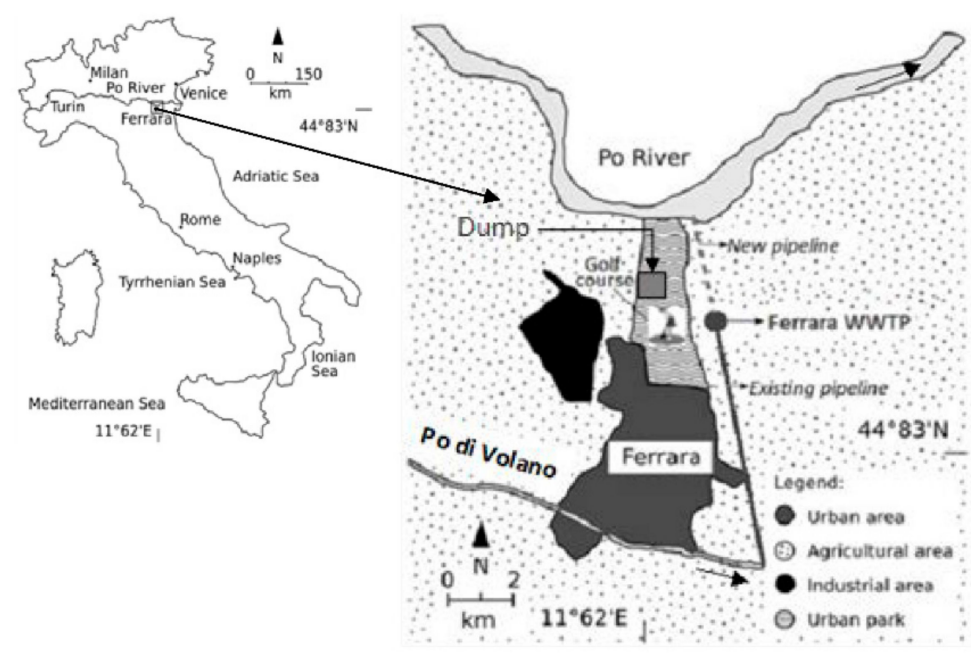

(A)

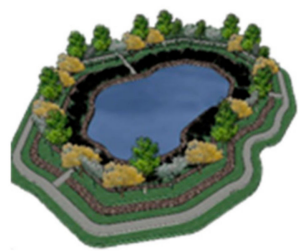

(B)

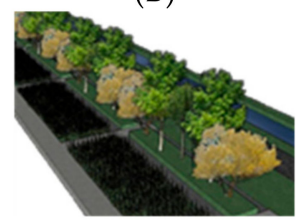

(C)

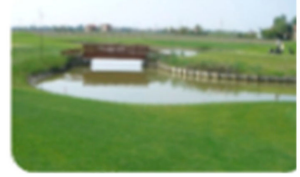

(D)

Figure 1. The study area; (A) map of the area under study and soil destination; (B) cycle path; (C) cycle path; (D) pond in the urban park.

The FIDEP project carried out a cost-benefit analysis by evaluating investment, operation, and maintenance costs on one hand, and agriculture, environmental and financial benefits as well as recreational benefit on the other. The latter was evaluated on the basis of CVM. For that study the sample included 146 resident families, a number considered sufficiently representative of all the families residing in the municipality of Ferrara.

In the current study we focus on this methodology. In particular, we present how the questionnaire used in the CVM was developed and how we enlarged the samples of interviewees to 400 families, 
equal to about $0.6 \%$ of the reference population. We analyze the collected answers in order to provide an example of the construction of a questionnaire for this purpose.

\subsection{The Model}

There are various CVM elicitation methods available in the literature (such as dichotomous choice, open-ended, bidding game, and payment card) and each of them has advantages and disadvantages [27].

In this study, the payment card approach was chosen from the various methods. According to this technique, respondents are asked to choose a single value, within a pre-packaged list of values [28]. There is also the possibility of selecting a value different from those proposed. The selected value represents the respondent's WTP. There are several advantages of the payment card approach compared to the other methods. Firstly, the WTP values are generated directly from the original data; secondly, since there is no single starting point, the possibility of excessive conditioning in the response is limited. However, the method also has some limitations. Although there is no single starting point, the predetermined range of responses can still condition the answers, causing the respondents to choose the most central values.

Starting from the structure of the data collected by means of the payment card, various WTP calculation models are available [29]. The model used in the current study is based on the Minimal Legal WTP Model (ML-WTP). According to this model, the chosen value of the payment card can be interpreted simply as a commitment to pay this specified amount [30]. In this legal approach, it is not allowed to assume a positive probability for WTP higher than the chosen value, as was done in other models [29]. The validity of the chosen model is based on the particular structure of the payment card adopted in this case: in fact, if the interviewee does not find a satisfactory WTP among the pre-printed options, he is required to express a specific value.

Given the different values from the payment card $\left(A_{i}\right)$ and their respective frequencies $\left(P_{i}\right)$ in the sample, it is possible to calculate the mean $(M L-W T P)$ and the median of the WTP:

$$
M L-W T P=\sum_{i=1}^{N} A_{i} \times P_{i}
$$

The median WTP can be obtained by sorting all answers according to their values and choosing the median one.

\subsection{Designing the Questionnaire}

The questionnaire was prepared and tested within the Department of Engineering of the University of Ferrara (Italy) before starting the interview in order to guarantee that the questions were clear and well defined. Once it had been validated, the interviews started and each time the importance of sincere replies and the guarantee of the respondent's anonymity were made clear. The respondent was also instructed to confirm his/her residence in the area of the study and he/she had to report his/her family's opinion.

The questionnaire consisted of three parts and a total of 27 questions, 21 being multiple-choice questions and the remaining 6 being open-ended. Table 2 reports the main issues related to the questions.

The first section was designed to elicit the respondent's level of interest in environmental issues. Such questions included whether the respondent felt it important to safeguard and defend the environment, in particular in the municipality of Ferrara, to increase green areas open to public access, and to involve the local population more in this safeguarding process. Questions were also aimed at evaluating the respondent's opinion on the upgrade of the existing local municipal WWTP by adopting conventional and natural systems, the latter being a combination of horizontal subsurface flow systems and small lagoons. This project would also include the construction of cycle paths within the urban park as well as the extension of the urban park area, from the first outskirts of the town 
towards the Po river, creating a total surface of 1000 ha. In this phase, diagrams and pictures of the proposed processes were shown and respondents were made aware that in 2010 the local planning act had declared this area to be of high environmental interest and had recommended its further exploitation for recreational activities.

The questions in the second section were devised to determine the respondent's opinions regarding the reuse project in question, and to discover, by means of a Payment Card with several monetary bidding options printed on it (from zero to $500 €$ with the possibility of specifying a different value from the reported values), how much they would be willing to contribute financially to a one-off payment. Before starting the interview, it was underlined that the questionnaire had been prepared for research purposes by a university research group with the aim of evaluating the willingness to pay for the construction of a polishing treatment by potential users of the enlarged urban park area.

Finally, the questions in the third part of the questionnaire were aimed at collecting socio-economic and demographic information pertaining to the interviewees; i.e., age, education level, occupation, family composition, net household income, and place of residence, as well as previous donations to voluntary environmentalist and social associations. In order to obtain a representative sample, all respondents included were residents in the different districts of the municipality of Ferrara, and their opinions were taken to reflect those of their family. During the interview, particular attention was given to the fact that the respondent's answer on the WTP should refer to his/her family nucleus.

At the end of each interview, the interviewer had to evaluate the reliability level of the replies collected for each section, providing a mark between 0 (low reliability, rejected) to 1 (high reliability, accepted). In this regard, the interviewers were previously trained, so as to be able to adequately inform the interviewee (in order to maximize the validity of his/her answers) and to evaluate the trustworthiness of his/her answers. The training was carried out with interview simulations. The interviewers learned to describe the problem and to assess whether the respondents' answers were sufficiently free from errors such as free rider attitudes, complacency towards the interviewer, or incorrect interpretation of the payment card and the payment vehicle.

Respondents with zero WTP had to answer a further filter question to find out whether this was a zero bid or a protest vote.

Table 2. Description of the main contents of the questionnaire.

\begin{tabular}{|c|c|}
\hline Phase & Contents \\
\hline $\begin{array}{l}\text { Interviewer Presentation- } \\
\text { Invitation to reply }\end{array}$ & $\begin{array}{l}\text { Presentation of the study, kind invitation to respond to the questionnaire, guarantee } \\
\text { of anonymity }\end{array}$ \\
\hline $\begin{array}{l}\text { Primary check } \\
\text { Selection of the respondents }\end{array}$ & Verification that respondents are resident in the municipality of Ferrara. \\
\hline $\begin{array}{l}\text { Section A: } \\
\text { Elicitation of the level of interest of the } \\
\text { respondent to environmental issues } \\
\text { (14 questions) }\end{array}$ & $\begin{array}{l}\text { Questions aiming to evaluate: respondent's interest towards TV programs, journals } \\
\text { on environment protection and safeguard; respondent's importance towards } \\
\text { safeguard of natural environment; respondent's practice to do outdoor sports or } \\
\text { recreational activities; respondent's importance towards safeguard of the landscape } \\
\text { of the municipality of Ferrara; respondent's opinion about current conditions of } \\
\text { the landscape in the municipality of Ferrara and the availability of green areas open } \\
\text { to the public; respondent's opinion about the necessity to preserve and safeguard } \\
\text { urban landscape;respondent's opinion about the possibility to involve local } \\
\text { community in supporting such costs even if relevant;respondent's knowledge of } \\
\text { the possibility to adopt natural treatments (constructed wetlands) to improve the } \\
\text { quality of the treated effluent;respondent's opinion about the possibility to complete } \\
\text { the current urban wastewater treatment plant of Ferrara by means of a polishing } \\
\text { systems realized within the urban park (close to the wastewater treatment plant) } \\
\text { allowing the construction of (safe) new green areas open to the public;respondent's } \\
\text { reasons of his/her possible opposition.After showing a map with the main issues } \\
\text { related to the project, photos of expected green areas and cycle paths, and a brief } \\
\text { explanation of the benefits for the local communities of the project, the interviewer } \\
\text { had to evaluate if the respondent was favorable or had some doubt towards } \\
\text { this proposal }\end{array}$ \\
\hline
\end{tabular}


Table 2. Cont

\begin{tabular}{|c|c|}
\hline Phase & Contents \\
\hline $\begin{array}{l}\text { Section B } \\
\text { Determination of the interest and } \\
\text { intention to contribute in the } \\
\text { construction. (3 questions) }\end{array}$ & $\begin{array}{l}\text { The interviewer underlined that this questionnaire was designed for investigating } \\
\text { and research purposes within a university project and remarked that the interview } \\
\text { core was to evaluate the level of contribution the residents could provide by means of } \\
\text { a payment card with several monetary bidding options printed on it. The payment } \\
\text { card was shown and the respondent was invited to express their availability.In case } \\
\text { of opposition to the contribution, the respondents were invited to explain } \\
\text { his/her reasons. }\end{array}$ \\
\hline $\begin{array}{l}\text { Section } C \\
\text { Collection of socio-economic and } \\
\text { demographic information } \\
\text { (10 questions) }\end{array}$ & $\begin{array}{l}\text { Questions aiming to know:if the respondent's family belongs or participates to } \\
\text { volunteering associations (with environmental or social aims);if the respondent's } \\
\text { family made/makes donations in cash to these associations;respondent's age, gender, } \\
\text { education level and current employmentrespondent's family composition, annual } \\
\text { average income, residence district. }\end{array}$ \\
\hline
\end{tabular}

\subsection{The Survey}

The survey was conducted by three university researchers, who are experts in wastewater treatment and reuse. It took place during the period between September 2011 and March 2012, mainly at supermarkets, railway station, schools, and the University of Ferrara. The respondents were randomly selected from different areas of the town of Ferrara and the numbers of respondents from each area were recorded and normalized to the total resident families of that area in order to guarantee the representability of the selected samples (Figure 2). The most recent census of Ferrara used for this study was Istat [31] and the corresponding resident population distribution is reported in Figure 2.

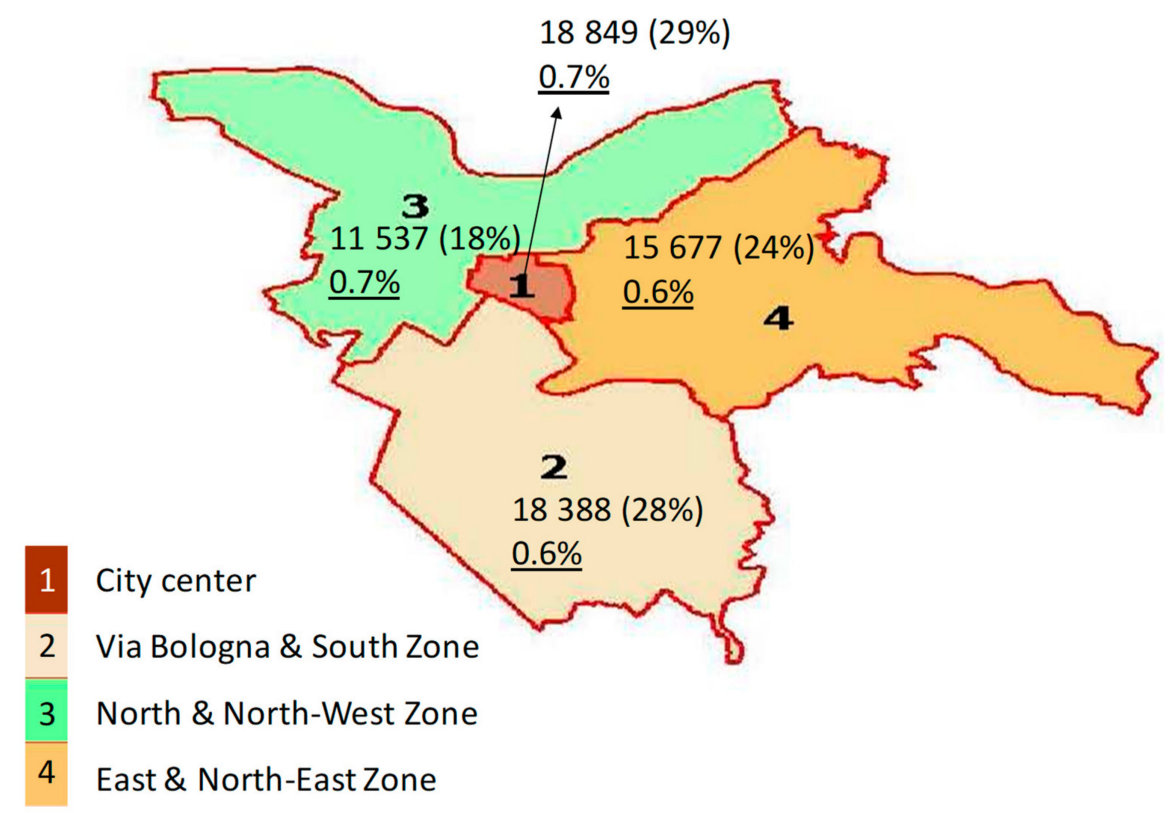

Figure 2. The four districts of Ferrara with the corresponding number of resident families and in brackets the percentage of the total and underlined the percentage of respondent families involved in the survey.

The number of respondents was defined on the basis of Slovin's formula $n=N /\left(1+N e^{2}\right)$ where $n$ is the sample size, $N$ is the universe of interest (that is all the potential respondents in the area of study) and $e$ is the desired (acceptable) margin of error [17]. This formula is usually adopted in statistical studies to define the sample size related to a certain level of confidence when a population behavior is unknown. It was found that, assuming $e=0.05$, for the specific investigation, the number of respondents had to be 400 across Ferrara. 


\section{Results and Discussion}

\subsection{Socio-Economic Characteristics and Awareness of the Problem}

Table 3 reports the descriptive statistics for the main characteristics of the respondents in terms of gender, age, living area, education level, job title, and yearly family income as often presented [17,23,32]. Fifty-four percent of the respondents were female and mostly in the age range of 36-56 years. With regard to their living area, the distribution among the four districts is similar to the distribution reported in Figure 2, referring to the whole population. Regarding education level, only $9.5 \%$ of the respondents have a primary school certificate as their maximum level of education, whereas the remaining percentage is fairly evenly divided between those who have a lower secondary school diploma, those with an upper secondary school diploma, and those with a university degree.

Table 3. Socio-demographic and economic characteristics of the respondents.

\begin{tabular}{|c|c|c|c|}
\hline \multirow{2}{*}{ Description } & & \multicolumn{2}{|c|}{ Sample Features } \\
\hline & & Number & $\%$ \\
\hline \multirow{2}{*}{ Gender } & Male & 184 & 46 \\
\hline & Female & 216 & 54 \\
\hline \multirow{12}{*}{ Age } & $22-26$ & 34 & 8.5 \\
\hline & $27-31$ & 52 & 13 \\
\hline & $32-36$ & 56 & 14 \\
\hline & $37-41$ & 74 & 18.5 \\
\hline & $42-46$ & 49 & 12.25 \\
\hline & $47-51$ & 38 & 9.5 \\
\hline & $52-56$ & 49 & 12.25 \\
\hline & $57-61$ & 29 & 7.25 \\
\hline & $62-66$ & 9 & 2.25 \\
\hline & $67-71$ & 6 & 1.5 \\
\hline & $72-76$ & 2 & 0.5 \\
\hline & $77-81$ & 2 & 0.5 \\
\hline \multirow{4}{*}{ Living area } & 1 City center & 125 & 31 \\
\hline & 2 Via Bologna \& South zone & 107 & 27 \\
\hline & 3 North \& North-West zone & 80 & 20 \\
\hline & 4 North \& North-East zone & 88 & 22 \\
\hline \multirow{4}{*}{ Educational qualification } & Nothing and primary school & 38 & 9.5 \\
\hline & Intermediate (lower secondary) school & 119 & 29.75 \\
\hline & High (upper secondary) school & 130 & 32.5 \\
\hline & University & 113 & 28.15 \\
\hline \multirow{6}{*}{ Job title } & Full time worker & 241 & 60.25 \\
\hline & Retired & 34 & 8.5 \\
\hline & Unemployed & 53 & 13.25 \\
\hline & Full time student & 23 & 5.75 \\
\hline & Housewife & 24 & 6 \\
\hline & Others & 25 & 6.25 \\
\hline \multirow{8}{*}{ Annual family income $(€)$} & $<12,000$ & 40 & 10 \\
\hline & $12,000-20,000$ & 78 & 19.5 \\
\hline & $20,000-30,000$ & 51 & 12.75 \\
\hline & $30,000-40,000$ & 66 & 16.5 \\
\hline & $40,000-50,000$ & 75 & 18.75 \\
\hline & $50,000-70,000$ & 46 & 11.5 \\
\hline & $70,000-100,000$ & 29 & 7.25 \\
\hline & $>100,000$ & 15 & 3.75 \\
\hline
\end{tabular}

With regard to job title, $60 \%$ are full time workers, $8.5 \%$ retired, and $13.25 \%$ are unemployed. $6 \%$ are temporary workers, part time workers, or workers who have been made redundant. Finally, referring to the yearly family income, the most populated ranges were 12,000-20,000€ and $40,000-50,000 €$, followed by 30,000-40,000 $€$ and 20,000-30,000 $€$. The two top classes correspond to families of, on average, between 1.8 and 3.1 members. 
All the respondents demonstrated an awareness of environmental problems in general and 380 of them agree that it is necessary to worry about the protection of the environment even if this leads to relevant costs. Of these 380 persons, 316 are regular users of green areas and use them for recreational activities.

Figure 3A shows the level of awareness of the respondents regarding the defense and safeguard of the natural environment and Figure $4 \mathrm{~A}$ shows the level of interest with regard to the local environment.

In both scenarios, most of the respondents expressed a high or fair level of importance. A comparison between the distribution in Figures 3 and 4 shows that most of the respondents are aware of the importance of green areas as well as of their care and safeguard. The percentage is less with regard to the local landscape (91\% versus 95\%). Respondents who are more sensitive to environmental issues are those with a higher educational level (Figures 3B and 4B). Even some people who do not regularly practice outdoor sports exhibited a high level of interest in and awareness of this topic.

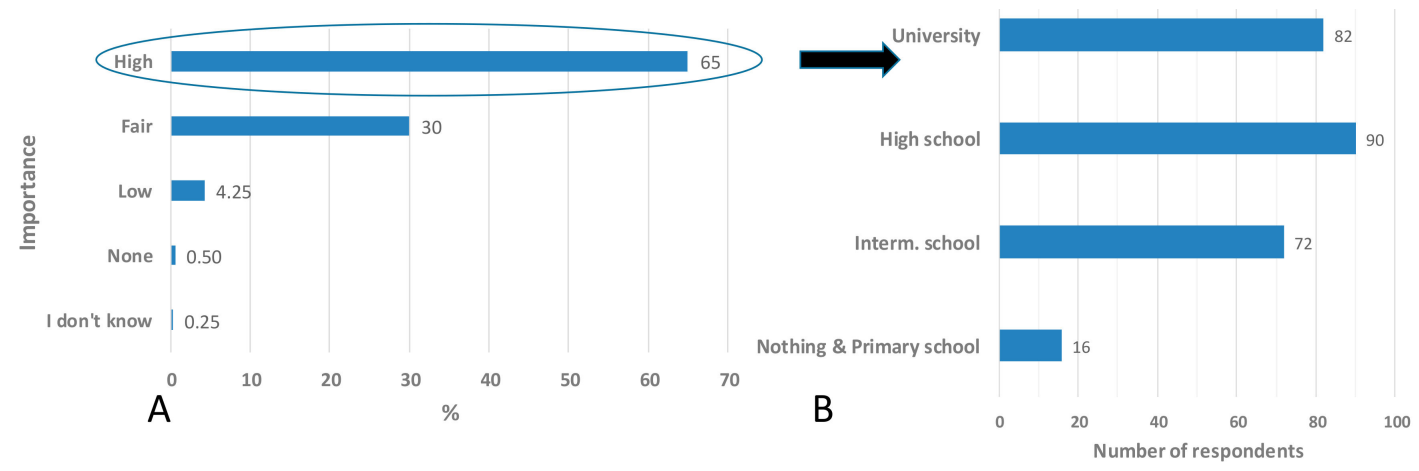

Figure 3. (A) Percentage distribution of respondents according to the importance they attribute to the defense of the natural environment and (B) distribution of respondents attributing high importance to environmental defense according to their education level.

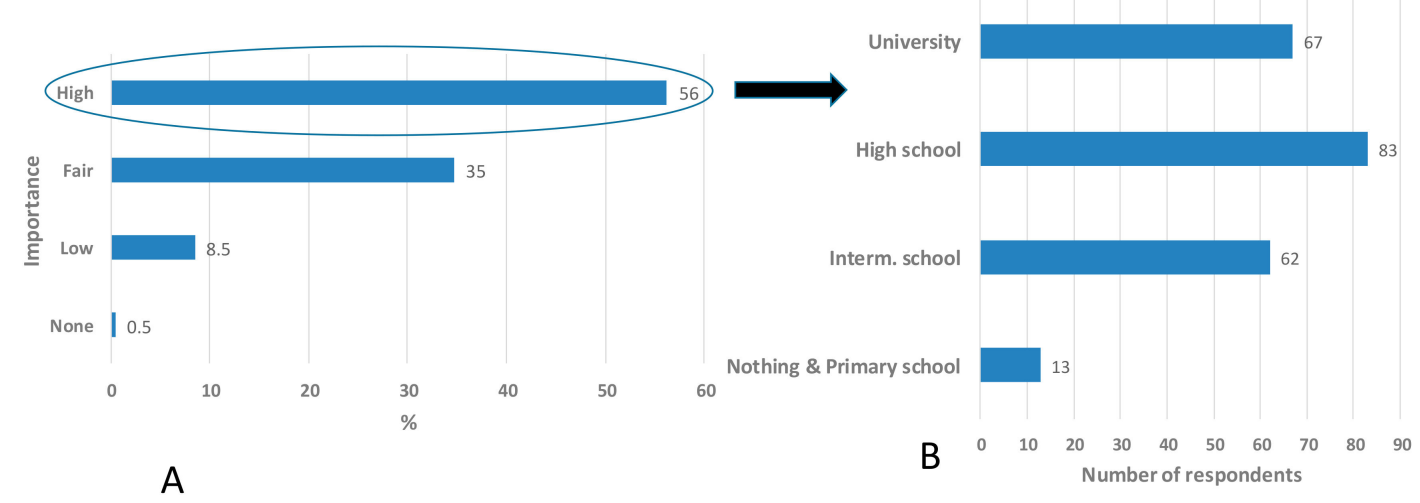

Figure 4. (A) Distribution of answers to the question: "How much importance do you attribute to the care and safeguard of the urban landscape of Ferrara?" and (B) distribution of educational level of respondents exhibiting high importance.

During the interview, a simplified diagram with a proposal for the upgrade of the existing wastewater treatment plant of the municipality of Ferrara was presented to the respondents. In fact, it was clearly explained that the upgrade of the existing wastewater treatment plant consists of the implementation of conventional treatment (rapid sand filters) and natural treatments such as subsurface flow, constructed wetlands, and lagoons in order to produce an effluent adequate for irrigation purposes. The construction of this polishing step should be within the urban park where, at the same time, well-equipped green areas (where users can stop and relax near small ponds) and cycle paths 
accessible to the public (around $3 \mathrm{~km}$ of paths within the urban park up to the river bank) would be realized, as shown in Figure 1.

To this end, the part of the project dedicated to recreational interventions was clearly explained, according to the rules that require the respondent to be familiar with the assets to be evaluated and be able to appreciate the relative benefits, both for use and non-use values [33].

It emerges that $86 \%$ of the respondents were favorable towards the development of this project, only $9 \%$ opposed it and 5\% had no opinion (Figure 5 left). The main reasons against the project were scarce interest in the problem (54\%), risk of bad odors (27\%) and a negative impact on human health $(11 \%)$. Similar reasons were also found in [10].
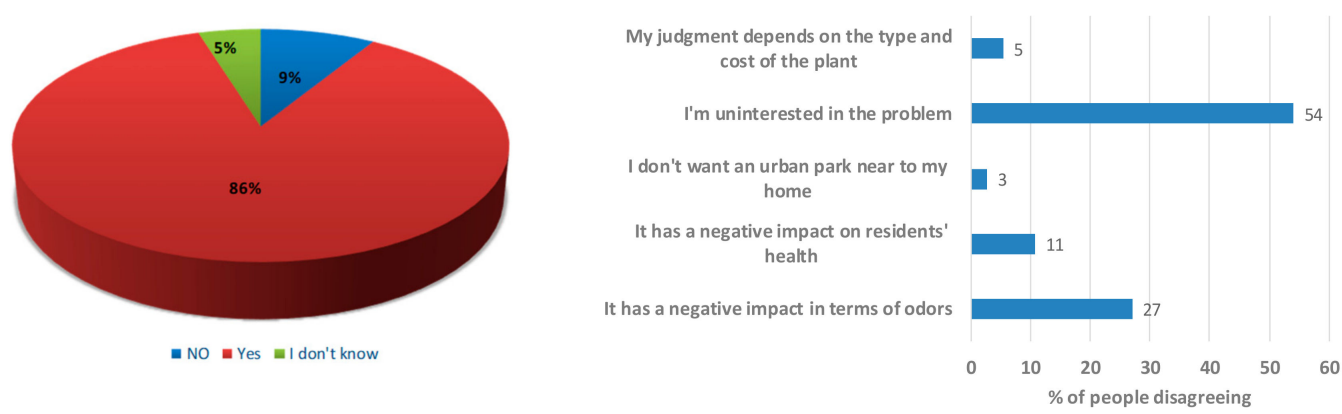

Figure 5. Percentage distribution of answers to the question: "Are you favorable towards the realization of this project?" (left) and distribution of the reasons against the project (right).

Statistical analyses like this were carried out in previous studies [10,17,23,32], aiming to correlate the collected replies on WTP to the socio-economic and demographic conditions of the respondents. Correlations were frequently found $[10,17,23,32]$, but in some cases they were not evident. In [15], for instance, it was found that the most important factor correlated WTP for a greywater treatment system was the fact that the respondents had previously considered the option of reclaimed water reuse. It is important to underline that great attention was commonly paid to opposite responses and protests [32].

\subsection{Estimation of Willingness to Pay}

Figure 6 reports the cumulative curve of WTP with regard to the number of respondents. It emerges that about $25 \%$ of the sample ( 96 respondents) are not willing to pay for the project. The WTP then increases regularly up to 360 respondents, with the tail respondents willing to contribute a higher amount: only one respondent selected $500 €$, two respondents $300 €$, and four $250 €$. A trend similar to this was also found in $[10,15]$.

The survey also included $8(2 \%)$ protest responses. Respondents, all full time workers, claimed: "There are more urgent actions needed in the municipality, for instance school maintenance, safety improvement etc". (3 responses), "European funds may be used for this purpose" (1 response), "I think an upgrade of the existing wastewater treatment plant is necessary but not within the urban park" ( 2 responses) and "There are already cycle paths that are not used" (1 response). Similar responses were found in $[10,12,34]$. 


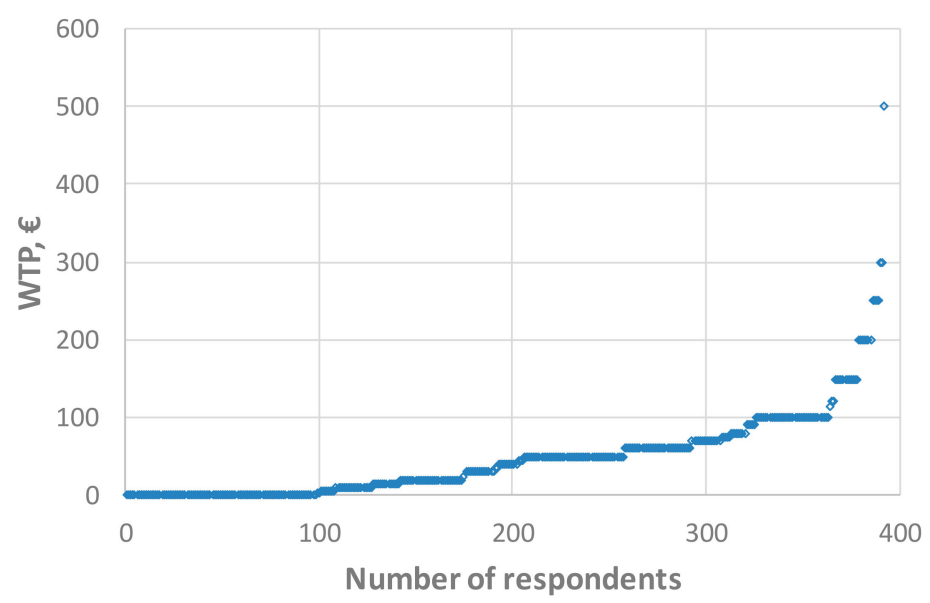

Figure 6. Distribution of the WTP among the respondents (protests are excluded).

As already highlighted, there were 96 (real zero) people who clearly disagreed with this kind of project and declared themselves unwilling to pay. The main reasons for their opposition were: respondents disagree with this kind of project $(34 \%)$, with voluntary private contributions $(26 \%)$, have some financial difficulties in supporting such a project $(12 \%)$ or suspect that the collected money could be used for other things (12\%) (see Figure 7). The survey also included 8 protest responses $(2 \%)$, as already discussed.

As highlighted above, after completing the interview, the interviewer had to evaluate the reliability of the collected responses. In this survey, apart from the 8 protests, some answers were not considered for the analysis due to the low reliability of the respondents, while all the rest were considered reliable and included in the analysis.

The highest WTP was equal to $500 €$, which was exhibited by only one respondent, whose answers were considered reliable.

As expected and as already found in the literature [17], the higher the annual family income of the respondent, the higher the corresponding average WTP (Figure 8), with only one exception for the category 50-70 k€, whose WTP was lower than the adjacent ones. The width of each box varies between 45 and $87 €$ except for the first category $(<12 \mathrm{k} €)$, which is the smallest one and equals $20 €$. With regard to the highest WTP (500€ and $300 €$ ), it was found that they correspond to respondents whose annual family income belongs to the ranges 40-50 k€ and 50-70 k€.

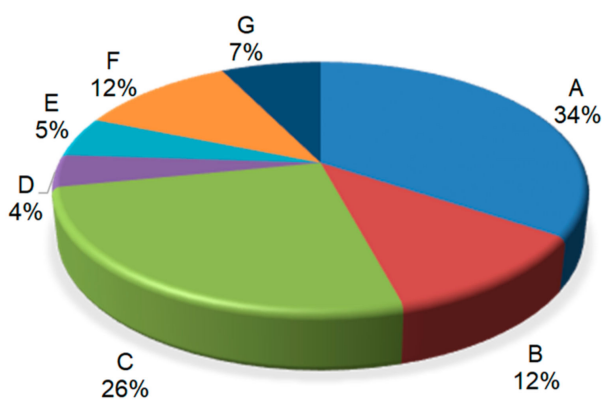

(A) The realization of this project does not justify my payment

(B) Realizing this project is not as important as other things

(C) I am against voluntary private contributions

(D) I think it's better to tax the citizens

(E) I do not believe that money is actually and efficiently used for implementation of the project

(F) I do not think that you are currently implementing this project

(G) I do not think this initiative can work

Figure 7. Reasons for opposition to the project (real zero). 


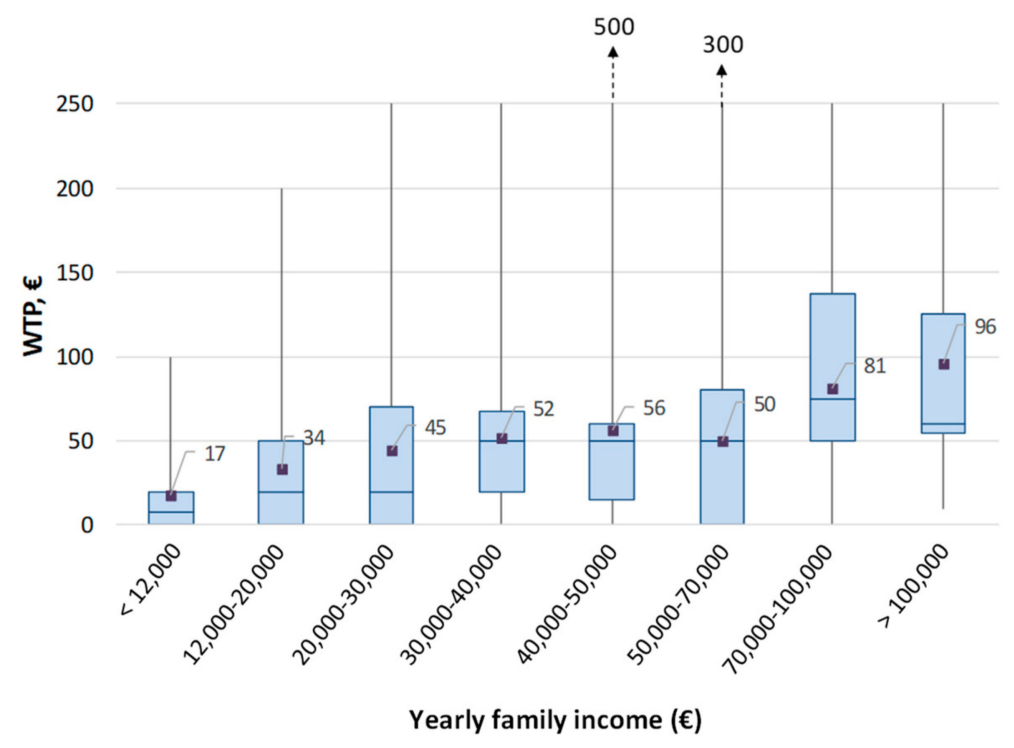

Figure 8. Distribution of WTP with respect to the annual family income.

There was a noticeable difference among WTP for respondents living in different residence areas: people living in the city center and in the east area were willing to pay more than the others (Figure 9). The reason behind this fact could be due to the low availability of green spaces in these two areas and the interest in creating new equipped green areas close to their homes. The influence of the district residence on the WTP was discussed also in [17] and, there, it was remarked that the people most interested were those residing closest the area under study or directly related to the project realization.

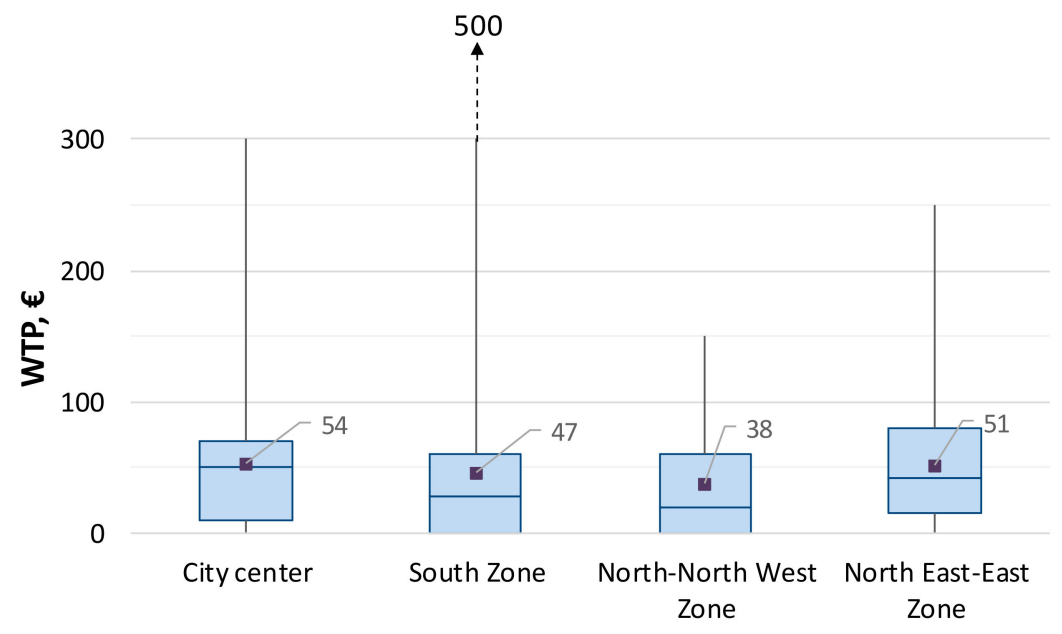

Figure 9. Distribution of WTP with respect to the resident area.

It is worth noting that respondents should have expressed their family opinion, but their education level could equally be of interest in analyzing their answers.

A rapid glimpse at Figure 10 shows that WTP seems to be related to the respondent's education level, as remarked in $[12,17,18]$. Respondents with a university degree express a familial WTP on average of $65 €$ and their corresponding variability range is the widest compared to the others, with the upper limit equal to $500 €$. Respondents with nothing but a primary school diploma declare much less (average WTP $23 €$, 75-percentile $40 €$ ). Those with a lower secondary (interm.) or an upper secondary (high) school diploma have a similar distribution of WTP. These results are in agreement with those reported by $[12,17,18]$. 


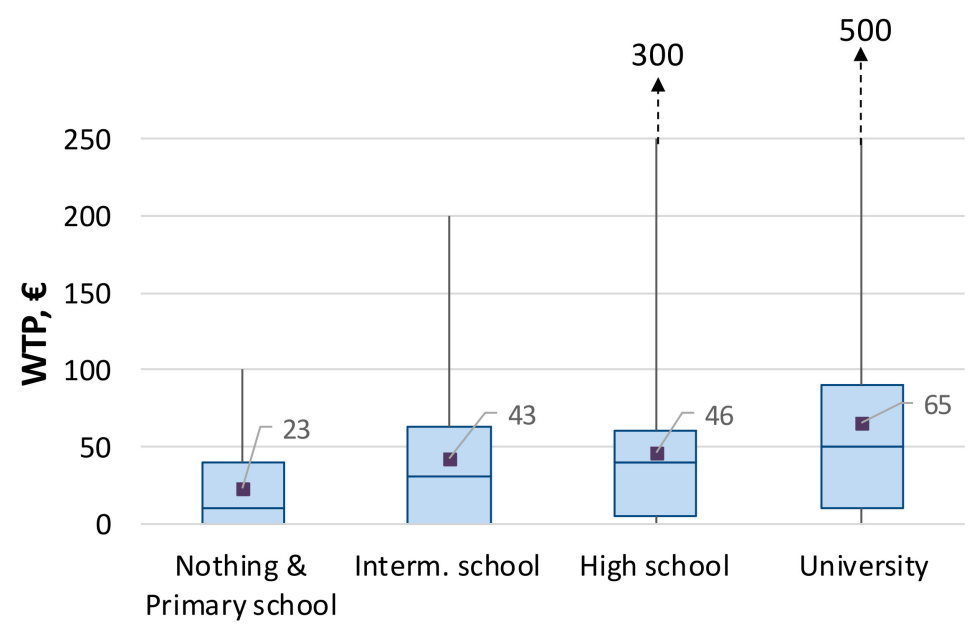

Education level

Figure 10. Distribution of WTP with respect to education level.

As expected, full time workers declare a higher WTP than the other groups (Figure 11): on average $52 €$ against $35 €$ for unemployed, $40 €$ for retired people, and $42 €$ for full time students. The relative high value of the housewife category may be justified as they may consider the proposed well-equipped green area places where they can potentially spend time with their family for recreational activities, or they may belong to a family with a high annual income. Moreover, full time workers exhibited the highest variability range with a maximum WTP of $500 €$ and students the smallest range (maximum of $100 €$ ).

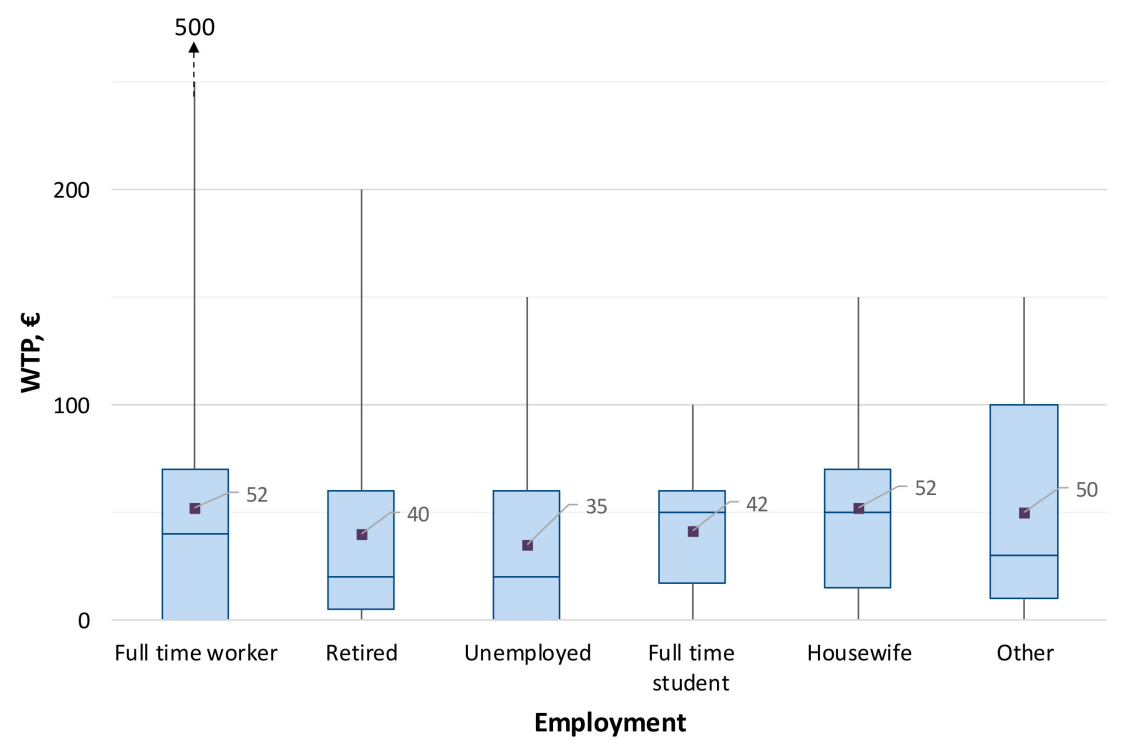

Figure 11. Distribution of WTP with respect to professional category.

With regard to the WTP distribution versus age intervals (Figure 12), it emerged that the average varied between 27 and $61 €$ for the categories $62-66$ and 67-71 years, respectively. The average for the first group ranged between 40 and $49 €$, for the second it was between 49 and $59 €$ and for the third group the average was between 27 and $61 €$. It is quite surprising that the third group exhibited such a high variability, although it includes both full-time workers and retired people with a wide spectrum of opinions on this issue. As for the specific age intervals, those who showed the highest variability in WTP are the four ranges between 37 and 46 years old. Another interesting result is that respondents belonging to the 72-76 group are always willing to provide a contribution of between 20 and $100 €$. A comparison 
with the results by [18] shows that differences occur among the age intervals and the highest values of WTP are associated to the central intervals (middle age).

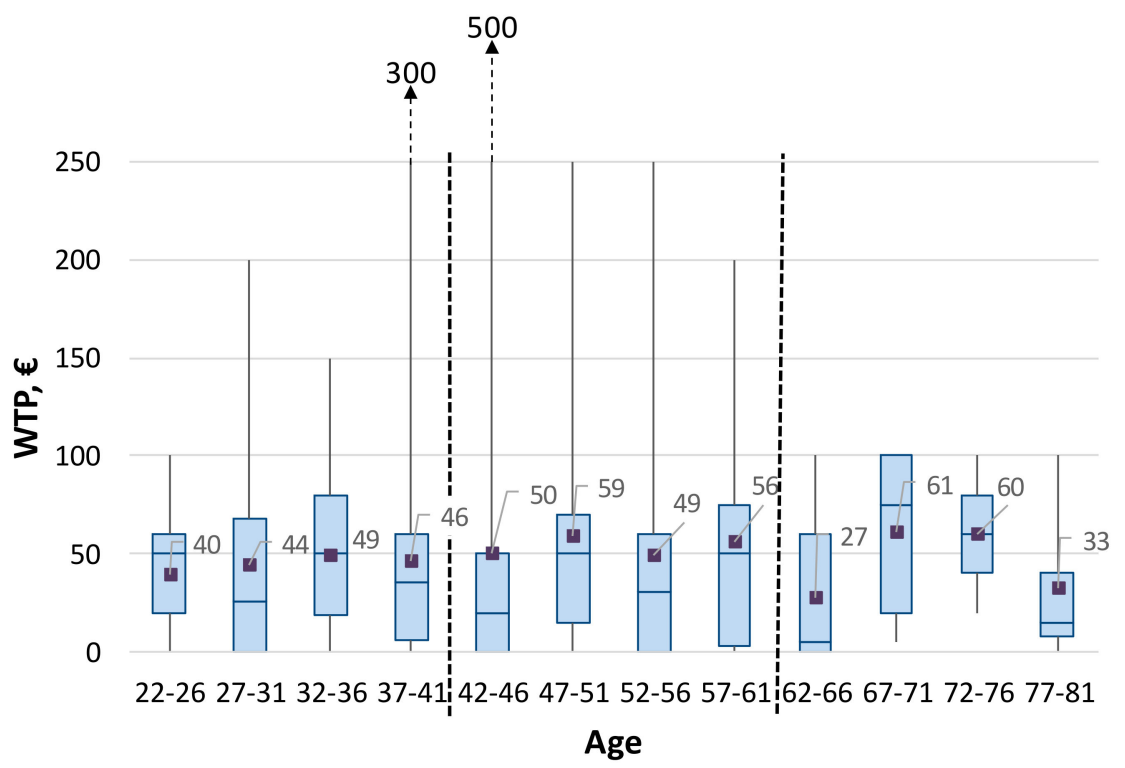

Figure 12. Distribution of WTP with respect to respondent age.

Based on the distribution of the families among the four districts and the average WTP found for each district, it emerged that the average WTP (ML-WTP, according to Equation (1)) for the municipality is equal to $48.10 €$ and the median WTP corresponds to $40 €$ (one-off payment).

To complete the study, in order to evaluate the sensitivity of the final result, a double sensitivity analysis was performed as a cautionary measure, based on the exclusion of some answers from the calculation. In the first scenario, the average WTA was recalculated, inserting the 8 protest responses, which could be considered answers by citizens who are not willing to pay anything for recreational services. In this case, the average WTA falls to $€ 47.14$, with a decrease of $2.0 \%$ compared to the baseline. The second analysis was carried out by eliminating the highest WTA case ( $€ 500)$ from respondents, despite being considered reliable by the interviewer. In this second case, the average WTA drops to $€ 46.95$, with a decrease of $2.4 \%$. Both analyses show that the sensitivity of the final outcome of the survey, with respect to these variations, is not particularly significant and they could represent an element, although not decisive, in favor of estimation validity.

In order to compare these results with those presented in other investigations, it is important to remark that available studies in literature (see Table 1) mainly refer to the WTP to contribute to the construction or the operation of a wastewater treatment able to guarantee the requested volume and quality of water for irrigation purposes or for non-potable reuse and not to the evaluation of the recreational benefit of a project. Moreover, it is also important to remark that analyses are commonly conceived with the volunteer contribution by WTP on a monthly or annual basis. To cite some cases reported in Table 1, in Segura (Spain) the average WTP for the reuse project of reclaimed water was found equal to $5.13 €$ month $^{-1}$ household ${ }^{-1}$ [12]; in Canada the average annual household WTP to avoid summer water restrictions via water supplies increased with reclaimed wastewater reuse was around $97 €$ year $^{-1}$ household $^{-1}$ (=8€ month $^{-1}$ household $^{-1}$ ) [23].

\section{Conclusions}

This paper presents and discusses a contingent valuation case study, aimed at evaluating the population's willingness to pay for recreational benefits provided by a water reuse project. The study is part of a cost-benefit analysis that estimates the economic feasibility of the entire project. 
The paper has provided methodological details regarding how the questionnaire used in the CVM was designed, how the collected responses were elaborated, and how the sensitivity analyses of the results were carried out.

The questionnaire was conceived in order to test respondents' knowledge and awareness of environmental issues and then to evaluate his/her intention to contribute to the realization of such a project.

The data processing, relating to a sample of 400 respondents, led to an estimate of the average family WTP of $48.10 €$, equal to a total reference population of 3,100,000 €. Two sensitivity analyses, carried out as a cautionary measure, showed a rather contained decrease in WTP (about $2 \%$ ). Comparing the results with those obtained in the previous study, based on the same reference population, but on a much smaller sample, there is a decrease of $11 \%$ in WTP. On one hand, the results confirm that this method, which involves the local population, is in accordance with the "polluter pays" principle and with the recommendation to involve users in the decision-making process (EU 60/2000 Water Framework Directive). It also allows the estimation of significant externalities, which can contribute to an evaluation of the total economic value of the projects. On the other hand, they highlight the necessity of paying attention to the sampling and questionnaire design phases, in order to maintain the reliability and validity of the estimates.

As it was highlighted in the literature [35], in Italy there is a lack of availability of basic economic data and specific surveys on the costs and benefits related to water projects, especially concerning environmental issues. This gap hinders planning and political decision-making. Estimates regarding environmental benefits are numerically few and methodologically heterogeneous. An extensive development of such investigations by the administrative bodies responsible for developing basin management plans is an improvement factor for the application of WFD. In fact, this development would allow the spread of "benefit transfer" applications [36], making public water management choices more efficient.

Author Contributions: For this research article all of the authors contributed extensively to the work. V.P. and Z.G. led this research, A.A.M. mainly carried out the interviews; all the three authors contributed to data analysis and to the manuscript writing and reviewing.

Funding: This work was financially supported by the Technopole Terra \& AcquaTech of the University of Ferrara (Funding: POR-FESR 2007-2013).

Conflicts of Interest: The authors declare no conflict of interest.

\section{Abbreviations}

$\begin{array}{ll}\text { CVM } & \text { contingent valuation method } \\ \text { ML-WTP } & \text { minimal legal willingness to pay } \\ \text { WTP } & \text { willingness to pay } \\ \text { WWTP } & \text { wastewater treatment plant }\end{array}$

\section{References}

1. Al-Isawi, R.H.K.; Almuktar, S.A.A.A.N.; Scholz, M. Monitoring and assessment of treated river, rain, gully pot and grey waters for irrigation of Capsicum annuum. Environ. Monit. Assess. 2016, 188, 287. [CrossRef] [PubMed]

2. Al-Isawi, R.H.K.; Scholz, M.; Al-Faraj, F.A.M. Assessment of diesel-contaminated domestic wastewater treated by constructed wetlands for irrigation of chillies grown in a greenhouse. Environ. Sci. Pollut. Res. 2016, 23, 25003-25023. [CrossRef] [PubMed]

3. Decree of the Ministry of Environment DM 185/2003. Regolamento Recante norme Tecniche per il riutilizzo delle Acque reflue in attuazione dell'art. Available online: www.gazzettaufficiale.it/eli/id/2003/07/23/ 003G0210/sg (accessed on 10 July 2018).

4. Verlicchi, P.; Al Aukidy, M.; Galletti, A.; Zambello, E.; Zanni, G.; Masotti, L. A project of reuse of reclaimed wastewater in the Po Valley, Italy: Polishing sequence and cost benefit analysis. J. Hydrol. 2012, 432-433, 127-136. [CrossRef] 
5. Verlicchi, P.; Galletti, A.; Masotti, L. A Promising Practice to Reclaim Treated Wastewater for Reuse: Chemical Disinfection Followed by Natural Systems. Desalination 2009, 247, 490-508. [CrossRef]

6. Kim, D.; Cho, Y.; McKennon, K.; Lowe, G.; Jung, S.; Kim, J. A successful transformation of conventional SBR to MBR at Indian casino and facility: A case study of Chumash Casino and Resort Water Reclamation Facility (WRF), water reuse perspectives. Environ. Earth Sci. 2017, 76, 578. [CrossRef]

7. Garcia, X.; Pargament, D. Reusing wastewater to cope with water scarcity: Economic, social and environmental considerations for decision-making. Resour. Conserv. Recycl. 2015, 101, 154-166. [CrossRef]

8. Fan, Y.; Chen, W.; Jiao, W.; Chang, A.C. Cost-benefit analysis of reclaimed wastewater reuses in Beijing. Desalin. Water Treat. 2015, 53, 1224-1233. [CrossRef]

9. Declercq, R.; Loubier, S.; Condom, N.; Molle, B. Socio-economic interest of treated wastewater reuse in agricultural irrigation and indirect potable water reuse: Clermont-Ferrand and Cannes case studies' cost-benefit analysis. Irrig. Drain. 2017. [CrossRef]

10. Tziakis, I.; Pachiadakis, I.; Moraitakis, M.; Xideas, K.; Theologis, G.; Tsagarakis, K.P. Valuing benefits from wastewater treatment and reuse using contingent valuation methodology. Desalination 2009, 237, 117-125. [CrossRef]

11. Hurlimann, A.; McKay, J. Contingent valuation by the community of indirect benefits of using recycled water-An Australian case study. Water Sci. Technol. Water Supply 2005, 5, 95-103. [CrossRef]

12. Alcon, F.; Pedrero, F.; Martin-Ortega, J.; Arcas, N.; Alarcon, J.J.; de Miguel, M.D. The non-market value of reclaimed wastewater for use in agriculture: A contingent valuation approach. Span. J. Agric. Res. 2010, 8, S187-S196. [CrossRef]

13. Bakopoulou, S.; Kungolos, A. Investigation of wastewater reuse potential in Thessaly region, Greece. Desalination 2009, 248, 1029-1038. [CrossRef]

14. Bakopoulou, S.; Polyzos, S.; Kungolos, A. Investigation of farmers'willingness to pay for using recycled water for irrigation in Thessaly region, Greece. Desalination 2010, 250, 329-334. [CrossRef]

15. De Simone Souza, H.H.; Paulo, P.L; Boncz, M.A. A constructed wetland system for residential greywater reuse: Economic feasibility of, and willingness to pay for. Desalin. Water Treat. 2017, 91, 336-348. [CrossRef]

16. Petousi, I.; Fountoulakis, M.S.; Stentiford, E.I.; Manios, T. Farmers' experience, concerns and perspectives in using reclaimed water for irrigation in a semi-arid region of Crete, Greece. Irrig. Drain. 2015, 64, 647-654. [CrossRef]

17. Chui, T.F.M.; Ngai, W.Y. Willingness to pay for sustainable drainage systems in a highly urbanised city: A contingent valuation study in Hong Kong. Water Environ. J. 2016, 30, 62-69. [CrossRef]

18. Liziński, T.; Wróblewska, A.; Rauba, K. Application of CVM method in the evaluation of flood control and water and sewage management projects. J. Water Land Dev. 2015, 24, 41-49. [CrossRef]

19. Nelson, N.M.; Loomis, J.B.; Jakus, P.M.; Kealy, M.J.; von Stackelburg, N.; Ostermiller, J. Linking ecological data and economics to estimate the total economic value of improving water quality by reducing nutrients. Ecol. Econ. 2015, 118, 1-9. [CrossRef]

20. Starkl, M.; Brunner, N.; Amerasinghe, P.; Mahesh, J.; Kumar, D.; Asolekar, S.R.; Sonkamble, S.; Ahmed, S.; Wajihuddin, M.; Pratyusha, A.; et al. Stakeholder views, financing and policy implications for reuse of wastewater for irrigation: A case from Hyderabad, India. Water 2015, 7, 300-328. [CrossRef]

21. Piriyapada, S.; Wang, E. Quantifying the costs and benefits of coastal water quality improvements in the Ko Chang marine national park, Thailand. Environ. Process. 2014, 1, 149-169. [CrossRef]

22. Kwak, S.; Yoo, S.; Kim, C. Measuring the willingness to pay for tap water quality improvements: Results of a contingent valuation survey in Pusan. Water 2013, 5, 1638-1652. [CrossRef]

23. Dupont, D.P. Water use restrictions or wastewater recycling? A Canadian willingness to pay study for reclaimed wastewater. Water Resour. Econ. 2013, 1, 61-74. [CrossRef]

24. Hurlimann, A.; McKay, J. Urban Australian using recycled water for domestic non-potable use-an evaluation of the attributes price, saltiness, colour and odour using conjoint analysis. J. Environ. Manag. 2007, 83, 93-104. [CrossRef] [PubMed]

25. Tussupova, K.; Berndtsson, R.; Bramryd, T.; Beisenova, R. Investigating willingness to pay to improve water supply services: Application of contingent valuation method. Water 2015, 7, 3024-3039. [CrossRef]

26. Decreto Legislativo (D. Lgs) 152/2006. Norme in Materia Ambientale. Available online: www. gazzettaufficiale.it/eli/id/2006/05/11/06A04475/sg (accessed on 10 July 2018). 
27. Boyle, K.J.; Johnson, F.R.; McCollum, D.; Desvousges, W.H.; Dunford, R.W.; Hudson, S.P. Valuing public goods: Discrete versus continuous contingent-valuation responses. Land Econ. 1996, 72, 381-396. [CrossRef]

28. Mitchell, R.C.; Carson, R.T. A Contingent Valuation Estimation of National Freshwater Benefits: Technical Reports to the U.S. Environmental Protection Agency; Resources for the Future: Washington, DC, USA, 1984.

29. Hackl, F.; Pruckner, G.J. On the gap between payment card and closed-ended CVM-answers. Appl. Econ. 1991, 31, 733-742. [CrossRef]

30. Harrison, G.W.; Kristrom, B. Interpretation of responses in CV surveys. In Current Issues in Environmental Economics; Johansson, P.O., Kristrom, B., Maler, K.G., Eds.; Manchester University Press: Manchester, UK; New York, NY, USA, 1995; pp. 35-57.

31. Istat. 2009. Available online: http:/ / demo.istat.it/archivio.html (accessed on 6 July 2018).

32. Del Saz Salazar, S.; García Menéndez, L. Estimating the non-market benefits of an urban park: Does proximity matter? Land Use Policy 2007, 24, 296-305. [CrossRef]

33. Cummings, R.G.; Brookshire, D.S.; Schulze, W.D. Valuing Environmental Goods, an Assessment of the Contingent Valuation Method; Rowman and Allanheld: Totowa, NJ, USA, 1986.

34. Genius, M.; Manioudaki, M.; Mokas, E.; Pantagakis, E.; Tampakakis, D.; Tsagarakis, K.P. Estimation of willingness to pay for wastewater treatment. Water Sci. Technol. Water Supply 2005, 5, 105-113. [CrossRef]

35. Viaggi, D.; Raggi, M.; Sardonini, L.; Ronchi, D. Implementation of the Water Framework Directive in Italy: State of the Art and Selected Research Issues; WFD Special Issue; Ambientalia SPI: Granada, Spain, 2010.

36. Brouwer, R.; Martin-Ortega, J.; Dekker, T.; Sardonini, L.; Andreu, J.; Kontogianni, A.; Michalis Skourtos, M.; Raggi, M.; Viaggi, D.; Pulido-Velazquez, M.; et al. Improving value transfer through socio-economic adjustments in a multicountry choice experiment of water conservation alternatives. Aust. J. Agric. Resour. Econ. 2015, 59, 1-21. [CrossRef]

(C) 2018 by the authors. Licensee MDPI, Basel, Switzerland. This article is an open access article distributed under the terms and conditions of the Creative Commons Attribution (CC BY) license (http:/ / creativecommons.org/licenses/by/4.0/). 